\title{
PENGARUH SARI KURMA PADA IBU POSTPARTUM TERHADAP BERAT BADAN BAYI DI BPM PIPIN HERIYANTI YOGYAKARTA
}

\section{EFFECT OF DATE PALM FRUITS ON POSTPARTUM TO INFANT WEIGHT IN INDEPENDENT MIDWIFERY PRACTICE PIPIN HERIYANTI YOGYAKARTA}

\author{
Dwi Yulinda ${ }^{1}$ \\ ${ }^{* 1}$ Program Studi Kebidanan (D-3) Fakultas Kesehatan Universitas Jenderal Achmad Yani Yogyakarta, \\ Kampus II Jl. Brawijaya Ring Road Barat Ambarketawang, Gamping, Sleman, \\ Email: liendha@yahoo.com, Indonesia
}

\begin{abstract}
Background: Galactogogues is one of pharmaticeutical agents to support the initiation, continuation or augmentatiton of breast milk product. Natural product of galactogogues contenst such as palm fruits. So many puerpural mother prefer using natural galactogogues to help incerase their milk supply is in observing successive measurment of the infant's naked weight. Nearly all infants lose weight for the first two to four days after birth. Postnatal weight loss on regaining birth weight are cliical parameters for monitoring an infat feeding status in the first week.

Objective: This study aimed to assess the effect of date palm fruits on postpartum to infant weight

Methods: Research was conducted on maternal postpartum which is divided into two groups. They are the control group; and the treatment group which was given dates palm fruit. Infant weight was measured at 7 day after birth. The analytical method used is Student T-test.

Results: Date Palm fruits increased infant weight which was significantly on firstweek increase in the treatment group compared to the control group at $p<0.05$.

Conclusion: Date Palm fruits is one of the alternatives that can be done to prevent infant lose weight.
\end{abstract}

Keywords: Date palm fruit, postpartum, infant weight

\section{PENDAHULUAN}

Pengeluaran ASI sangat bergatung dari hormon oksitosin yang menyebabkan kontraksi pada sel epitel alveoli pada letdown reflek sehingga akan membantu proses laktasi. Kontraksi pada sel tersebut diakibatkan adanya hisapan oleh mulut bayi yang selanjutnya akan dikirimkan hipofisis posterior sehingga terjadi pengeluaran oksitosin. ${ }^{1}$ Kalium yang memproduksi galaktogogus merupakan agen farmasetikal, makanan, atau suplementasi herbal yang berfungsi untuk membantu memperlancar pengeluaran ASI. Beberapa tumbuhan yang mengandung galaktogogus dapat membantu pengeluaran dan produksi ASI antara lain daun katuk, fenugreek, dan kurma. Galaktogogus dapat menginduksi laktasi dengan menekan antagonis reseptor dopamin sehingga terjadi peningkatan produksi prolaktin. Selain untuk meningkatkan produksi ASI, tumbuhan tersebut juga memberikan efek mencegah perdarahan. $^{2}$

Kurma (Phoenix dactylifera) Kurma megandung hormon oksitosin yang diproduksi oleh neurohipofisis dengan menghambat sekresi dopamin. ${ }^{3}$ Oksitosin 
disekresikan dari terminal saraf melalui eksositosis akibat adanya peningkatan $\mathrm{Ca}^{2+}$ intraseluler karena depolarisasi membran akson yang membuka kanal kalsium. Oksitosin dialirkan melalui darah berikatan dengan reseptornya yang terdapat di mioepitel payudara, otot polos uterus, dan otak, serta mengaktivasi sistem fosfolipase yang meningkatkan kalsium intraseluler. ${ }^{4}$

ASI merupakan makanan yang mampu mencukupi seluruh kebutuhan bayi baik fisik, psikologi, sosial, maupun spiritual karena mengandung nutrisi, hormon, unsur kekebalan, faktor pertumbuhan, anti alergi. ${ }^{5}$ Walaupun ibu dalam kondisi kekurangan gizi sekalipun, ASI tetap mengandung nutrisi esensial yang cukup untuk bayi dan mampu mengatasi infeksi melalui komponen sel fagosit dan imunoglobulin. ASI akan merangsang pembentukan daya tahan tubuh bayi sehingga ASI berfungsi pula sebagai imunisasi aktif. ${ }^{6,7}$

Asupan nutrisi yang kurang pada bayi dapat menyebabkan malnutrisi, gizi buruk, kurangnya daya tahan tubuh, perkembangan otak tidak maksimal, pertumbuhan tubuh juga akan terhambat. Sejak masa kandungan sampai dengan berusia dua tahun merupaka masa yang sangat kritis atau disebut dengan gold periode untuk perkembangan otak yang sangat cepat. Sehingga apabila terdapat masalah pada masa kritis akan memberikan dampak jangka panjang terhadap kehidupan di masa depan. Faktor risiko berat badan bayi turun dapat disebabkan karena ekskresi cairan ekstravaskuler yang berlebihan dan kekurangan nutrisi. Peningkatan berat badan yang adekuat akan sangat membantu pertumbuhan dan perkembangan bayi secara normal dan optimal, peningkatan berat badan tersebut tentunya bersifat bertahap sesuai umur. Jika terjadi penurunan berat badan bayi maka berat badan harus bertambah atau melebihi berat badan lahir pada usia 2 minggu. ${ }^{8,9}$

Bayi yang mendapatkan kecukupan ASI dapat diketahui dengan beberapa cara antara lain dengan menimbang bayi setiap minggu dengan kenaikan berat badan usia 19 bulan 10-15 gram/ hari, atau 125 gram/minggu atau $500 \mathrm{gram} /$ bulan. Pada 7 hari pertama berat badan bayi tidak mengalami penurunan $10 \%$ dari berat badan pada saat lahir. Selain itu, observasi frekuensi BAK dalam 24 jam, durasi tidur setelah menyusu, serta proses dan, waktu menyusui juga dapat digunakan untuk memantau kecukupan ASI. ${ }^{1,7}$

\section{BAHAN DAN CARA PENELITIAN}

Penelitian ini dilakukan secara eksperimental dengan Rancangan Acak Lengkap (RAL) menggunakan post test dengan kelompok kontrol (Post Test Only Control Group Design). Penelitian ini dilakukan pada ibu postpartum dan bayi. Tempat penelitian ini di BPM Pipin Heriyanti, Yogyakarta pada bulan Mei-September 2017. 
Penelitian ini telah mendapatkkan persetujuan dari Komite Etik Fakultas Kesehatan Universitas Jenderal Achmad Yani Yogyakarta.

Pada penelitian ini responden dibagi menjadi 2, yaitu kelompok kontrol dan kelompok perlakuan yaitu ibu postpartum yang diberikan sari kurma. Selanjutnya pada hari ketujuh dilakukan penimbangan berat badan bayi.

\section{HASIL DAN PEMBAHASAN}

Pengujian data menggunakan Anova $(p<0,05)$ yang sebelumnya dilakukan Uji normalitas menggunakan Shapiro Wilk dan uji homogenitas menggunakan Levene test. Dan dilanjutkan pengujian LSD.

Analisis data dengan menggunakan penghitungan uji statistik. Saphiro-Wilk untuk mengetahui normalitas data ( $p>0,05)$, Levene digunakan untuk menentukan homogenitas data $(p>0,05)$. Student $t$ test digunakan untuk mengetahui apakah ada perbedaan antara kelompok perlakuan dengan kelompok kontrol terhadap peningkatan berat badan bayi. Uji Kai Kuadrat untuk mengetahui apakah ada perbedaan pada 2 kelompok perlakuan dan kontrol didapatkan $(p<0,05)$ sehingga disimpulkan ada perbedaan antara kelompok kontrol dan perlakuan terhadap berat badan bayi.

Berdasarkan tabel 1 Karakteristik responden ibu pada kelompok kontrol maupun perlakuan sebagian besar berusia reproduksi sehat yaitu 20-35 tahun. Usia reproduksi ibu sangat menentukan kesiapan alat reproduksi terhadap kualitas bayi yang dilahirkan. Pada usia kurang dari 20 tahun atau lebih dari 35 tahun memiliki kecenderungan kurang terpenuhinya gizi untuk pertumbuhan dan perkembangan janin, sehingga meningkatkan risiko melahirkan bayi BBLR, dan komplikasi saat persalinan. ${ }^{10,11}$

Tabel 1. Karakteristik Responden

\begin{tabular}{lcccc}
\hline \multirow{2}{*}{ Karakteristik } & \multicolumn{2}{c}{ Kontrol } & \multicolumn{2}{c}{ Perlakuan } \\
\cline { 2 - 5 } \multicolumn{1}{c}{ Usia ibu } & $\mathbf{n}$ & $\%$ & $\mathbf{n}$ & $\%$ \\
\hline$<20$ tahun & 0 & 0 & 1 & 7 \\
20-35 tahun & 15 & 93 & 13 & 81 \\
$>35$ tahun & 1 & 7 & 2 & 12 \\
\hline Jenis kelamin bayi & & & & \\
Laki-laki & 8 & 50 & 8 & 50 \\
Perempuan & 8 & 50 & 8 & 50 \\
\hline Sumber: Data Primer 2017. & &
\end{tabular}

Jenis kelamin bayi pada kelompok kontrol dan perlakuan berjumlah sama antara laki-laki dan perempuan. Jenis kelamin menunjukan perbedaan peningkatan berat badan, sehingga kebutuhan nutrisinya juga berbeda. Peningkatan berat badan bayi lakilaki minimal sebanyak 250 gram setiap minggu, sedangkan bayi perempuan minimal sebanyak 200 gram setiap minggu. Pemantauan berat badan bayi mengikuti grafik monitoring berat badan menurut jenis kelamin terdapat pada Kartu Menuju Sehat. ${ }^{9}$

Berdasarkan tabel 2 hasil rata-rata peningkatan berat badan bayi pada kelompok perlakuan lebih banyak daripada kelompok kontrol. Penimbangan berat badan pada bayi sangat penting dilakukan setiap minggu 
sebagai upaya untuk pemantauan terhadap kecukupan ASI, selain itu observasi frekuensi BAK dalam 24 jam, durasi tidur setelah menyusu, serta proses dan, waktu menyusui juga dapat digunakan untuk memantau kecukupan ASI. ${ }^{1,7}$

Tabel 2. Perbandingan berat badan bayi Kelompok Kontrol Dengan Perlakuan Sari Kurma

\begin{tabular}{lccc}
\hline Kelompok & $\begin{array}{c}\text { Rata-Rata } \\
\text { Berat badan } \\
\text { bayi (gram) }\end{array}$ & $\begin{array}{c}\text { Z- } \\
\text { hitung }\end{array}$ & $\begin{array}{c}\text { p- } \\
\text { value }\end{array}$ \\
\hline Kontrol & 120 & $-2,283$ & 0,000 \\
Perlakuan & 170 & & \\
\hline \multicolumn{2}{l}{ Sumber: Data Primer 2017. } & &
\end{tabular}

Air Susu Ibu (ASI) memiliki manfaat yang sangat banyak baik untuk ibu maupun bayi. Kandungan gizi berupa karbohidrat, lemak, vitamin, mineral, taurin, laktosa, DHA, AA, omega 3 dan 6 sangat penting dibutuhkan untuk pertumbuhan dan perkembangan bayi. Sedangkan bagi tubuh ibu, dengan menyusui akan mengurangi risiko perdarahan, membantu mengecilkan uterus dengan adanya peningkatan hormon oksitosin, mengurangi kejadian anemia, dapat digunakan sebagai alat kontasepsi alamiah, membantu penyerapan lemak tubuh ibu sehingga lebih langsing, mengurangi risiko kanker payudara, lebih ekonomis, praktis, dan meningkatkan rasa kepercayaan diri. $^{7,12}$

Berat badan merupakan salah satu cara untuk menentukan kesehatan bayi, dan menggambarkan komposisi tubuh bayi secara keseluruhan. Berat badan bayi yang kurang dapat menggambarkan kisaran pola makan yang kurang maupun kandungan gizinya. $^{19}$

Kebutuhan bayi akan zat gizi jika dibandingkan dengan orang dewasa dapat dikatakan sangat kecil. Namun jika diukur berdasarkan persentase berat badan, kebutuhan bayi akan zat gizi melampaui kebutuhan orang dewasa, hampir dua kali lipat. Makanan pertama dan utama bayi adalah ASI yang sangat sesuai untuk memenuhi kebutuhan bayi dalam segala hal, yakni karbohidrat yang berupa laktosa, asam lemak tak jenuh ganda, protein laktalbumin yang mudah dicerna, kandungan vitamin dan mineralnya banyak, rasio kalsium-fosfat sebesar 2:1 yang merupakan kondisi ideal bagi penyerapan kalsium, dan mengandung zat anti infeksi. Zat-zat yang terkandung dalam ASI juga memberikan manfaat untuk perkembangan otak, meningkatkna daya tahan tubuh dari infeksi pada saluran pernafasan dan pencernaan., ${ }^{7,12}$

Pengeluaran ASI di pengaruhi oleh hormon oksitosin yang menyebabkan kontraksi pada sel epitel alveoli pada letdown reflek. Beberapa faktor yang dapat memengaruhi pengeluaran ASI antara lain frekuensi menyusui, berat badan bayi lahir, usia kehamilan, jumlah paritas, stres, konsumsi alkohol maupun tembakau, dan penggunaan kontrasepsi hormonal kombinasi. ${ }^{18}$

Isapan bayi sangat penting untuk menstimulasi ujung saraf sensorik pada 
puting susu dan areola payudara, dan impuls tersebut berjalan sepanjang serat aferen menuju korda spinalis yang selanjutnya akan bergerak ke traktus spinotalamikus lateral, dorsal, dan ventral menuju otak tengah. Serat eksitatorik diproyeksikan secara langsung ke neuron oksitosin pada hipotalamus, mengakibatkan pelepasan oksitosin oleh hipofisis. Dengan adanya oksitosin yang dikeluarkan hipofisis maka pengeluaran ASI dapat terjadi. ${ }^{15,16}$

Oksitosin dapat diperoleh dengan berbagai cara baik melalui oral berupa terapi, atau makanan (kurma, fenugreek), intranasal, intra-muscular, maupun dengan pemijatan yang merangsang keluarnya hormon oksitosin. Penelitian menyebutkan bahwa dalam kurma mengandung galaktogogus yang merupakan agen farmasetikal, makanan, atau suplementasi herbal yang berfungsi untuk membantu memperlancar pengeluaran ASI. $^{13}$ Kandungan gizi pada kurma (Phoenix dactylifera) sangat lengkap yaitu potasium, glisin, dan threonin dapat meningkatkan aktivitas produksi prolaktin. Potasium/kalium merupakan salah satu mineral yang menghalangi reseptor dopamin, dan sehingga merangsang pelepasan oksitosin untuk pengeluaran ASI. Oksitosin disekresikan dari terminal saraf melalui eksositosis akibat adanya peningkatan $\mathrm{Ca}^{2+}$ intraseluler karena depolarisasi membran akson yang membuka kanal kalsium.
Oksitosin dialirkan melalui darah berikatan dengan reseptornya yang terdapat di mioepitel payudara, otot polos uterus, dan otak, serta mengaktivasi sistem fosfolipase yang meningkatkan kalsium intraseluler. ${ }^{14,16}$

Pada kelompok perlakuan rata-rata peningkatan berat badan lebih benyak dibandingkan kelompok kontrol, maka dapat disimpulkan bahwa ada pengaruh pemberian sari kurma pada ibu postpartum terhadap peningkatan berat badan bayi. Sari kurma dapat meningkatkan pengeluaran ASI sehingga dapat memenuhi kebutuhan nutrisi bagi bayi.

Faktor-faktor yang memengaruhi berat badan bayi antara lain frekuensi menyusui, asupan gizi pada ibu postpartum, paritas. Pada penelitian ini beberapa faktor tersebut pada hari ke-7 sebelum penimbangan berat badan bayi diabaikan, sehingga menjadi kelemahan dalam penelitian ini.

\section{TERIMA KASIH}

1. Kuswanto Hardjo, dr., M.Kes, Dekan Fakultas Kesehatan Universitas Jenderal Achmad Yani Yogayakarta, email: info@stikesayaniyk.ac.id

2. Deby Zulkarnain Rahardian Syah, S.Kep.,Ns., MMR, Ketua PPPM Fakultas Kesehatan Universitas Jenderal Achmad Yani Yogayakarta, email: pppm@unjaya.ac.id 


\section{KEPUSTAKAAN}

1. Suradi, S., dkk.. Indonesia Menyusui. Jakarta: IDAI; 2010.

2. Gabay,MP.2002. Galactogogues: Medications That Induce Lactation. J Hum Lact. 2002; volume 18, (3), Hal. 274-279

3. Satuhu,S. Kurma Khasiat Dan Aneka Olahannya. Jakarta: Plus; 2010.

4. Fraser, DM \& Cooper, MA. At A Glace Sistem Endokrin. Jakarta: EMS; 2009.

5. Wahyuni, S. Asuhan Neonatus Bayi \& Balita Penuntun Belajar Praktek Klinik, Jakarta, EGC; 2012.

6. Munasir Z. dan Kurniati N. Air Susu Ibu dan Kekebalan Tubuh. In : IDAI. Bedah ASI : Kajian dari Berbagai Sudut Pandang IImiah. Jakarta: Balai Penerbit FKUI; 2008.

7. Roesli, U. Mengenal ASI Ekslusif. Jakarta: Trubus Agriwida; 2005.

8. Supariasa, I.D.N., dkk. Penilaian Status Gizi, Jakarta: EGC; 2011.

9. Suradi, R. Rohsiswatmo, R., Dewi, R., Endyarni, B., Rustina, Y. Perawatan Bayi Berat Bdan Lahir Rendah dengan Metode Kanguru, Jakarta: HTA Indonesia; 2008.

10. Proverawati, A., Asfuah, S. Gizi Untuk Kebidanan, Yogyakarta: Mulia Medika; 2009.
11. Behrman, RE., Kleigman, RM. Arvin, AM. IImu Kesehatan Anak, Jakarta: EGC;2012.

12. Arifin, M.H.D. Pemberian ASI Ekslusif dan Faktor-faktor yang Memengaruhinya. Digitized USU library. 2004.

13. Sakka AE, Salama M, Salama K. The Effect of Fenugreek Herbal Tea and Palm Dates on Breast Milk Production and Infant Weight. Journal of Pediatric Sciences. 2014.6:e202

14. Ali, A., Waly, M., Essa, M., and Devarajan,S. Nutritional and Medicinal Value of Date Fruit Dates. 368-370

15. Greenstein, B \& Wood, D. At A Glace Sistem Endokrin. Edisi Kedua. Jakarta: EMS; 2010.

16. Fraser, DM \& Cooper, MA. At A Glace Sistem Endokrin. Jakarta: EMS; 2009.

17. Varney, Helen., Kriebs, Jan M., Gegor C.L.. Buku Ajar Asuhan Kebidanan. Edisi 4 Volume 2. Jakarta : EGC; 2008.

18. Kodrat, laksono. Dahsyatnya ASI \& Laktasi. Yogyakarta: Media Baca; 2010.

19. Widyastuti, Danis., Widyani, Retno. Panduan Perkembangan Anak 0-1 tahun. Jakarta: Puspaswara; 2005. 